\title{
Video Animasi Bertema Tri Hita Karana pada Aspek Afektif
} Anak Usia Dini

\section{Ni Putu Mega Diantari ${ }^{1}$, Anak Agung Gede Agung²}

1,2 Jurusan Pendidikan Dasar, Universitas Pendidikan Ganesha, Singaraja, Indonesia

\section{ART ICLE INF O}

Article history:

Received 18 April 2021

Revised 19 April 2021

Accepted 01 Juli 2021

Available online 25 Agustus 2021

Kata Kunci:

Tri Hita Karana, Aspek Afektif

Keywords:

Tri Hita Karana, Affective Aspect

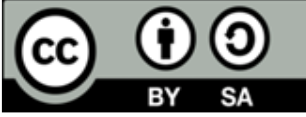

This is an open access article under the CC BY-SA license.

Copyright $(2021$ by Author. Published by Universitas Pendidikan Ganesha.

\begin{abstract}
A B S T R A K
Kebijakan pembelajaran daring memberikan dampak pada kurang efektifnya pengembangan kemampuan afektif anak. Masa pandemi juga membuat proses pembelajaran lebih dominan dilaksanakan menggunakan handphone. Penelitian ini bertujan untuk menghasilkan rancang bangun dan mengetahui validitas media video animasi bertema Tri Hita Karana pada aspek afektif anak usia dini. Jenis penelitian ini adalah penelitian pengembangan (research and development) dengan menggunakan model pengembangan ADDIE. Subjek penelitian ini berjumlah 5 orang diantaranya ahli isi pembelajaran 1 orang, ahli desain pembelajaran dan ahli media pembelajaran 1 orang, dan pada uji perorangan menggunakan 3 orang anak usia dini kelompok B. Data dikumpulkan menggunakan metode kuesioner. Data diolah menggunakan teknik analisis deskriptif kuantitatif. Hasil penelitian menunjukkan bahwa pada uji ahli isi memperoleh skor $100 \%$ dengan kategori sangat baik, uji ahli desain memperoleh skor $85 \%$ dengan kategori sangat baik, hasil uji ahli media memperoleh skor $83 \%$ dengan kategori baik, dan hasil uji coba perorangan memperoleh hasil $93 \%$ dengan kategori sangat baik. Berdasarkan hasil uji tersebut dapat dinyatakan bahwa produk media video animasi bertema Tri Hita Karana pada aspek afektif ini layak digunakan untuk anak usia dini.
\end{abstract}

\section{A B S T R A C T}

Online learning policies have an impact on the ineffectiveness of developing children's affective abilities. The pandemic period also makes the learning process more dominant carried out using mobile phones. This study aims to produce designs and determine the validity of animated video media with the theme Tri Hita Karana on affective aspects of early childhood. This type of research is research and development using the ADDIE development model. The subjects of this study were 5 people including 1 learning content expert, 1 learning design expert and 1 learning media expert, and in the individual test using 3 early childhood children in group B. Data were collected using the questionnaire method. The data was processed using quantitative descriptive analysis techniques. The results showed that the content expert test got a score of $100 \%$ in the very good category, the design expert test got a score of $85 \%$ in the very good category, the results of the media expert test got a score of $83 \%$ in the good category, and the results of the individual test got $93 \%$ results. with very good category. Based on the test results, it can be stated that the animated video media product themed Tri Hita Karana on the affective aspect is suitable for use for early childhood.

\section{PENDAHULUAN}

Anak merupakan individu yang unik, berbeda dan memiliki karakteristik sendiri sesuai dengan tahapan usianya masing-masing. Perkembangan pada anak dari mulai lahir hingga memasuki pendidikan dasar merupakan masa keemasan sekaligus masa kritis dalam tahapan kehidupan manusia, yang akan menentukan perkembangan anak selanjutnya (Hasanah \& Muryanti, 2019; Nasution et al., 2019). Pertumbuhan dan perkembangan anak usia dini perlu diarahkan pada fisik, kognitif, sosial emosional, bahasa, dan kreativitas yang seimbang sebagai peletak dasar yang tepat guna pembentukan pribadi yang utuh dan merangsang pertumbuhan kecerdasan otak pada anak (Isbayani et al., 2015; Priyanto, 2014). Perkembangan anak perlu diperhatikan sejak dini, karena hal tersebut juga akan mempengaruhi masa depan anak. Pendidikan anak usia dini memiliki peran penting dalam mempersiapkan anak di masa mendatang. Pendidikan anak usia dini bersifat futuristik yang artinya anak-anak dipersiapkan untuk 
mampu menghadapi masa yang akan datang dengan tetap memiliki budi pekerti yang luhur yang sesuai degan ajaran agamanya (Nuraeni et al., 2019; Wirman et al., 2018). Pembelajaran untuk anak usia dini diimplementasikan dalam pendidikan PAUD. Dalam pendidikan PAUD anak tidak hanya diajarkan untuk meningkatkan kemampuan kognitif, melainkan juga diajarkan dan dilatih untuk mengembangkan kemampuan pada ranah afektif. Ranah afektif merupakan salah satu ranah yang penting untuk dikembangkan dalam membentuk anak yang memiliki nilai atau norma. Anak usia dini memiliki perkembangan aspek afektif yang berbeda-beda. Hal tersebut perlu diperhatikan untuk menetapkan dan menetapkan strategi pembelajaran yang tepat digunakan berdasarkan aspek afektifnya (Rahmayani et al., 2019; Wulandari \& Suyanta, 2019). Ranah Afektif merupakan ranah yang berkaitan dengan sikap dan nilai yang mencakup watak, perasaan, minat, sikap, dan emosi (Fitri \& Idris, 2019; Nurjanah, 2017).

Hanya saja proses pembelajaran pada masa pandemi saat ini memberikan keterbatasan pada proses pembelajaran, proses pembelajaran yang dilakukan secara daring memberikan keterbatasan aktivitas belajar pada siswa (Dewi \& Sadjiarto, 2021). Guru kesulitan menyampaikan materi ke pada siswa dan guru kesulitan dalam memberikan evaluasi pada siswa, hal ini menyebabkan tidak tercapainya tujuan pembelajaran (Ariesca et al., 2021). Khususnya pada anak usia dini yang tentu sulit untuk dibiasakan dalam proses pembelajaran secara daring yang tidak memberikan kesempatan pada siswa untuk bermain sambil belajar (Muammar \& Suhartina, 2018). Hal ini sejalan dengan temuan hasil observasi di TK Ratna Kumara yang menunjukkan bahwa pelaksanaan pembelajaran daring anak usia dini hanya berorientasi pada grup WhatsApp dan menggunakan aplikasi Zoom dengan menggunakan metode penugasan. Hal ini tentu berdampak negatif terhadap perkembangan anak dalam ranah afektif, kognitif dan psikomotor. Khususnya pada ranah afektif, dimana siswa sulit untuk menyesuaikan diri dan belajar bersikap dan berinteraksi dengan lingkungan sekolah dan teman.

Dari permasalahan tersebut dapat dilihat bahwa terdapat kesenjangan antara kondisi ideal dengan kondisi yang diharapkan untuk proses pembelajaran anak usia dini. Anak usia dini memerlukan banyak fasilitas belajar yang menunjang siswa untuk memiliki kegiatan belajar yang sesuai untuk mengajak siswa bermain sambil belajar. Kegiatan pembelajaran yang menoton seperti penugasan saja tidak dapat membuat siswa memiliki pengalaman belajar yang bermakna bagi anak usia dini. Anak usia dini memiliki karakteristik belajar yang berbeda dengan anak sekolah pada jenjang yang lebih tinggi, hal ini tentu membuat guru harus lebih kreatif dalam memilih strategi, metode dan media pembelajaran yang tepat untuk mengajarkan anak usia dini. Ada banyak cara yang bisa dilakukan untuk mengoptimalkan perkembangan hasil belajar anak yaitu salah satunya dengan memaksimalkan penggunaan media pembelajaran. Terlebih lagi dengan perkembangan teknologi dapat memberikan kesempatan guru untuk mengembangkan berbagai media pembelajaran yang bisa digunakan dalam proses pembelajaran (Muhson, 2010; Pradilasari et al., 2019). Video animasi merupakan salah satu media pembelajaran yang berisi berbagai komponen seperti gambar, teks, dan suara yang dapat membuat proses pembelajaran lebih efektif, efisien dan menyenangkan (Luthfiyah \& Rakhmawati, 2018; Sudaryono et al., 2018). Penggunaan teknologi sangat membantu proses pembelajaran di kelas menjadi lebih bervariatif dan dapat membantu perkembangan kognitif, afektif dan psikomotorik anak (Akbar, 2016; Rosalina \& Nugrahani, 2019). Video animasi menjadi salah satu perpaduan yang inovatif antara pembelajaran dengan teknologi dan dibuat dengan visual yang menarik, sehingga menciptakan pembelajaran yang interaktif (Jaelani et al., 2020).

Untuk memaksimalkan penggunaan video animasi dalam pengembangan kemampuan afektif anak usia dini, maka video animasi dapat dibuat dengan berlandaskan falsafah Tri Hita Karana. Tri Hita Karana merupakan salah satu konsep agama Hindu yang mengajarkan bahwa manusia dapat mencapai kemakmuran dan kebahagiaan melalui hubungan harmonis dengan lingkungan alam (Palemahan), hubungan harmonis antara manusia dengan manusia (Pawongan), serta hubungan harmonis antara manusia dengan tuhan (Parahyangan) untuk mengantarkan manusia menuju kebahagiaan (Artana, 2016). Jika dalam pembelajaran diterapkan ajaran Tri Hita Karana maka siswa dapat mengembangkan sikap dan prilaku atau ranah afektif dalam kegiatan pembelajaran (Mandra \& Dhammananda, 2020; Ardithayasa \& Yudiana, 2020). Konsep Tri Hita Karana harus menjadi pedoman bagi guru untuk melaksanakan pendidikan anak usia dini dengan patokan bahwa pendidikan anak usia dini itu penting, karena perkembangan anak pada masa tersebut sangat pesat (Nofikasari et al., 2019; Suandi \& Pamungkas, 2019). Anak usia dini memiliki kepekaan yang tinggi terhdap berbagai rangsangan, sehingga guru harus bisa memberikan rangsangan atau perlakuan yang tepat untuk memaksimalkan perkembangan hasil belajar anak.

Beberapa penelitian yang berkaitan dengan pengembangan video animasi pembelajaran dan Tri Hita Karana menyebutkan bahwa media video animasi bermuatan Tri Hita Karana memiliki kualifikasi baik, sehingga layak untuk dikembangkan dan dibelajarkan kepada siswa (Mahardika et al., 2019). Penelitian selanjutnya juga menyatakan bahwa video pembelajaran berbasis Tri Hita Karana memiliki 
kekhasan dengan memvisualisasikan nilai-nilai Tri Hita karana sehingga tertanam nilai-nilai karakter pada siswa, sehingga sangat valid dan layak digunakan pada muatan IPS kelas V SD (Wahyudi et al., 2021). Penelitian lainnya juga mengungkapkan hal serupa mengenai penggunaan media video animasi, dimana video animasi layak diterapkan dalam pembelajaran anak usia dini (Dewi et al., 2021). Berdasarkan beberapa penelitian tersebut dapat dikatakan bahwa media video animasi sangat layak digunakan dalam proses pembelajaran anak, selain itu penggunaan konsep Tri Hita Karana juga mampu menanamkan nilainilai sosial yang positif kepada anak. Hanya saja pada penelitian terdahulu belum terdapat penelitian yang mengkolaborasikan media video animasi dengan konsep Tri Hita Karana, sehingga penelitian ini difokuskan pada pengembangan video animasi bermuatan Tri Hita Karana. Adapun tujuan dari penelitian ini yakni untuk menghasilkan rancang bangun dan mengetahui validitas media video animasi bertema Tri Hita Karana pada aspek afektif anak usia dini.

\section{METODE}

Penelitian ini merupakan jenis penelitian pengembangan (research and development) yang dikembangkan menggunakan model pengembangan ADDIE. Model pengembangan ADDIE terdiri dari 5 tahap yaitu tahap analisis (analyze), perancangan (design), pengembangan (development), implementasi (implementation), evaluasi (evaluation). Rancangan penelitian menggunakan model ADDIE dapat dilihat pada gambar 1.

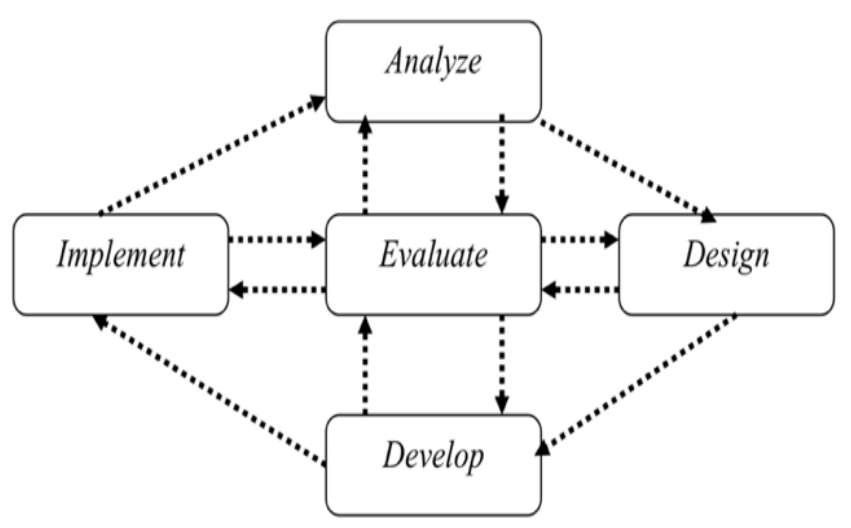

Gambar 1. Tahap Penelitian Model ADDIE (Sumber: Tegeh, dkk., 2014)

Subjek yang terlibat dalam penelitian ini berjumlah 5 orang diantaranya adalah 1 orang ahli isi pembelajaran, 1 orang ahli desain pembelajaran dan ahli media pembelajaran, dan pada uji perorangan menggunakan 3 orang anak usia dini kelompok B TK Negeri Pembina Badung. Ahli isi pembelajaran, ahli desain pembelajaran, dan ahli media pembelajaran merupakan seorang dosen yang mengajar di Jurusan Pendidikan Dasar di Universitas Pendidikan Ganesha. Subjek pada uji coba perorangan menggunakan tiga orang anak kelompok B TK Negeri Pembina Badung yang terdiri dari anak berkemampuan tinggi, sedang, dan rendah. Metode pengumpulan data yang digunakan pada penelitian ini adalah metode kuesioner. Kuesioner diberikan pada uji validitas yang dilakukan oleh para ahli dan juga uji coba perorangan yang dilakukan oleh anak anak kelompok B TK. Kuisioner yang diberikan kepada subjek digunakan untuk mengumpulkan informasi terkait menentukan kelayakan produk multimedia interaktif. Data yang sudah terkumpul pada kuesioner kemudian diolah dengan teknik analisis deskriptif kuantitatif. Instrumen yang digunakan pada penelitian ini menggunakan kuesioner. Adapun kisi-kisi instrumen yang digunakan untuk mengumpulkan data pada uji validitas dan uji coba perorangan dapat dilihat pada tabel 1,2,3, dan 4

Tabel 1. Kisi - Kisi Instrumen Ahli Isi Pembelajaran

\begin{tabular}{|c|c|c|c|c|}
\hline No. & Aspek & Indikator & No. Butir & Jumlah Butir \\
\hline \multirow[t]{2}{*}{1.} & \multirow[t]{2}{*}{ Kurikulum } & $\begin{array}{l}\text { 1. Kesesuaian materi dengan kompetensi dasar } \\
\text { dan indicator }\end{array}$ & 1,2 & \multirow[t]{2}{*}{ 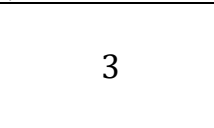 } \\
\hline & & 2. Kesesuaian tujuan pembelajaran & 3 & \\
\hline \multirow{4}{*}{2.} & \multirow{4}{*}{ Materi } & 1. Ketepatan materi & 4 & \\
\hline & & 2. Kemenarikan materi & 5 & \\
\hline & & 3. Materi mudah dipahami & 6 & \\
\hline & & 4. Kebenaran materi & 7 & 8 \\
\hline
\end{tabular}




\begin{tabular}{|c|c|c|c|c|}
\hline No. & Aspek & Indikator & No. Butir & Jumlah Butir \\
\hline \multirow{7}{*}{3.} & \multirow{7}{*}{ Kebahasaan } & 5. Kesesuaian materi dengan kehidupan nyata & 8 & \\
\hline & & 6. Materi didukung media yang tepat & 9 & \\
\hline & & 7. Pentingnya materi & 10 & \\
\hline & & $\begin{array}{l}\text { 8. Materi membantu mengingat kemampuan dan } \\
\text { pengetahuan sebelumnya }\end{array}$ & 11 & \\
\hline & & 1. Bahasa yang digunakan mudah dipahami & 12 & \multirow{3}{*}{3} \\
\hline & & $\begin{array}{l}\text { 2. Bahasa yang digunakan sesuai dengan } \\
\text { karakteristik anak }\end{array}$ & 13 & \\
\hline & & 3. Penggunaan Bahasa yang tepat dan konsisten & 14 & \\
\hline 4. & Evaluasi & 1. Kejelasan target hasil belajar & 15 & 1 \\
\hline & \multicolumn{3}{|c|}{$\begin{array}{c}\text { Jumlah } \\
\end{array}$} & 15 \\
\hline
\end{tabular}

Tabel 2. Kisi - Kisi Instrumen Desain Pembelajaran

\begin{tabular}{|c|c|c|c|c|}
\hline No. & Aspek & Indikator & No. Butir & Jumlah Butir \\
\hline \multirow{2}{*}{1.} & \multirow{2}{*}{ Tujuan } & 1. Kejelasan tujuan pembelajaran & 1,2 & \multirow[t]{2}{*}{ ( } \\
\hline & & 2. Kosistensi antara tujuan, materi dan evaluasi & 3 & \\
\hline \multirow{5}{*}{2.} & \multirow{5}{*}{ Strategi } & 1. Kegiatan pembelajaran dapat memotivasi anak & 4 & \multirow{5}{*}{6} \\
\hline & & 2. Memberikan kesempatan pada anak belajar mandiri & 5 & \\
\hline & & $\begin{array}{l}\text { 3. Penyampaian materi menarik dan sesuai dengan } \\
\text { karakteristik anak }\end{array}$ & 6,7 & \\
\hline & & $\begin{array}{l}\text { 4. Penyampaian materi memberikan langkah-langkah } \\
\text { yang logis }\end{array}$ & 8 & \\
\hline & & 5. Memberikan petunjuk belajar & 9 & \\
\hline 3. & Evaluasi & $\begin{array}{l}\text { 1. Diberikan evaluasi untuk mengukur kemampuan } \\
\text { anak }\end{array}$ & 10 & 1 \\
\hline & & Jumlah & & 10 \\
\hline
\end{tabular}

Tabel 3. Kisi - Kisi Instrumen Media Pembelajaran

\begin{tabular}{|c|c|c|c|c|}
\hline No. & Aspek & Indikator & No. Butir & Jumlah Butir \\
\hline \multirow{9}{*}{1.} & \multirow{8}{*}{$\begin{array}{c}\text { Desain } \\
\text { pesan }\end{array}$} & 1. Desain tampilan & 1 & \multirow{8}{*}{8} \\
\hline & & $\begin{array}{l}\text { 2. Penggunaan gambar yang mendukung } \\
\text { pembelajaran }\end{array}$ & 2 & \\
\hline & & 3. Keterbacaan teks & 3 & \\
\hline & & $\begin{array}{l}\text { 4. Penggunaan jenis huruf, ukuran dan spasi tulisan } \\
\text { yang tepat }\end{array}$ & 4 & \\
\hline & & $\begin{array}{l}\text { 5. Komposisi dan kombinasi warna yang tepat dan } \\
\text { serasi }\end{array}$ & 5 & \\
\hline & & 6. Penggunaan animasi yang tepat & 6 & \\
\hline & & 7. Penggunaan dubbing yang tepat & 7 & \\
\hline & & 8. Penggunaan sound effect yang tepat & 8 & \\
\hline & & 1. Kemudahan penggunaan media & 9 & \multirow{3}{*}{3} \\
\hline \multirow[t]{2}{*}{2.} & rengopi & 2. Media dapat digunakan secara berulang & 10 & \\
\hline & & 3. Diberikan petunjuk penggunaan & 11 & \\
\hline \multirow{4}{*}{3.} & $\begin{array}{l}\text { Ketepata } \\
\text { n, }\end{array}$ & $\begin{array}{l}\text { 1. Media yang digunakan dapat membantu } \\
\text { pemahaman materi }\end{array}$ & 12 & \multirow{4}{*}{4} \\
\hline & Teknik, & Konsistensi dengan tema & 13 & \\
\hline & Kejelasa & 3. Media dapat membantu anak dalam proses belajar & 14 & \\
\hline & $\mathrm{n}$ & 4. Keakuratan materi yang digunakan & 15 & \\
\hline & \multicolumn{3}{|c|}{ Jumlah } & 15 \\
\hline
\end{tabular}

(Sumber: Suartama, 2016 dengan modifikasi peneliti) 
Tabel 4. Kisi - Kisi Instrumen Uji Coba Perorangan

\begin{tabular}{|c|c|c|c|c|}
\hline No. & Aspek & Indikator & No. Butir & Jumlah Butir \\
\hline \multirow{5}{*}{1.} & \multirow{4}{*}{ Desain Pesan } & 1. Desain produk & 1 & \multirow{4}{*}{4} \\
\hline & & 2. Keterbacaan teks & 2 & \\
\hline & & 3. Kejelasan gambar & 3 & \\
\hline & & 4. Kejelasan suara & 4 & \\
\hline & & 1. Ketepatan isi materi & 5 & \multirow{3}{*}{3} \\
\hline \multirow[t]{2}{*}{2.} & Materi & 2. Kemudahan pemahaman materi & 6 & \\
\hline & & 3. Kebermanfaatan media pembelajaran & 7 & \\
\hline \multirow{2}{*}{3.} & \multirow{2}{*}{ Pengoperasian } & 1. Kemudahan pengoperasian & 8 & \multirow{2}{*}{2} \\
\hline & & 2. Diberikan petunjuk penggunaan & 9 & \\
\hline \multirow[t]{2}{*}{4.} & Motivasi & $\begin{array}{l}\text { 1. Media membantu anak dalam proses } \\
\text { belajar }\end{array}$ & 10 & 1 \\
\hline & & Jumlah & & 10 \\
\hline
\end{tabular}

Metode analisis data yang digunakan pada penelitian pengembangan ini adalah metode analisis deskriptif kualitatif dan metode analisis deskriptif kuantitatif. Metode analisis deskriptif kualitatif adalah cara pengolahan data dengan menyusun secara sistematis data dalam bentuk kalimat, kata dan kategori sehingga ditemukan simpulan secara umum (Agung, 2014). Teknik analisis data ini dilakukan dengan mengelompokkan data kualitatif yang berupa hasil wawancara, kriteria nilai kelayakan produk, komentar, tanggapan, kritik, dan saran perbaikan. Hasil analisis data kemudian digunakan untuk merevisi produk yang dikembangkan. Metode deskriptif kuantitatif adalah mengolah data dengan menyusun secara sistematis ke dalam bentuk angka-angka ataupun persentase untuk mendapatkan simpulan secara umum (Agung, 2014). Dalam penelitian ini, analisis deskriptif kuantitatif digunakan untuk mengolah data kualitatif yang diperoleh melalui angket dalam bentuk skor. Menggunakan skala likert dengan kategori pilihan genap. Mencari persentase skor angket dengan membandingkan jumlah keseluruhan jawaban yang diberikan responden dengan skor maksimal atau ideal, kemudian dikali 100\%. Kriteria yang digunakan untuk memberikan makna dan pengambilan keputusan dapat dilihat pada tabel 5 .

Tabel 5. Konversi Tingkat Pencapaian dengan Skala 5

\begin{tabular}{cccc}
\hline No. & Tingkat Pencapaian (\%) & Kualifikasi & Keterangan \\
\hline 1 & $90-100$ & Sangat Baik & Tidak Perlu Direvisi \\
2 & $75-89$ & Baik & Sedikit Revisi \\
3 & $65-79$ & Cukup & Direvisi Secukupnya \\
4 & $55-64$ & Kurang & Banyak Hal Yang Direvisi \\
5 & $1-54$ & Sangat Kurang & Diulang Membuat Produk \\
\hline
\end{tabular}

\section{HASIL DAN PEMBAHASAN}

Hasil

Hasil pada penelitian ini akan membahas dua hal secara umum yaitu rancang bangun dan validitas media video animasi berbasis Tri Hita Karana. Rancang bangun pada penelitian ini dikembangkan menggunakan model pengembangan ADDIE yang terdiri dari lima tahapan yaitu analisis (analyze), perancangan (design), pengembangan (development), implementasi (implementation), evaluasi (evaluation). Validitas dilakukan untuk mengetahui kelayakan media video animasi yang dilakukan oleh ahli isi pembelajaran, ahli desain pembelajaran, ahli media pembelajaran, dan anak kelompok B TK Ratna Kumara pada uji coba perorangan. Tahap pertama yaitu tahap analisis yang dilakukan dengan menganalisis dan mengidentifikasi beberapa kebutuhan dalam pengembangan media. Analisis dilakukan dengan menganalisis kebutuhan dan permasalahan proses pembelajaran daring, serta menemukan KD dan indikator yang sesuai. Pada tahap analisis ditemukan bahwa proses pembelajaran daring mengalami kendala pada saat pelaksanaannya. Permasalahan yang ditemukan di TK Ratna Kumara yakni kurangnya media dan alat evaluasi yang bisa menjadi solusi dalam pembelajaran daring. Sistem pembelajaran yang diterapkan pada pembelajaran daring hanya berorientasi pada grup WhatsApp dan menggunakan aplikasi Zoom dengan menggunakan metode penugasan, sehingga berdampak pada kurangnya interaksi antara guru dan siswa. Selain menganalisis permasalahan pada proses pembelajaran, analisis juga dilakukan pada ketersediaan fasilitas pembelajaran. Hasil analisis menunjukkan bahwa sebanyak 25 anak, orang tuanya sudah memiliki smartphone dengan sistem operasi android dan beberapa juga sudah memiliki 
laptop. Disamping itu fasilitas yang ada di TK Ratna Kumara sudah dilengkapi dengan LCD walaupun tidak berisi di setiap kelas. Hal tersebut menjadi aspek pendukung pengembangan media pembelajaran video animasi.

Tahap pengembangan kedua yakni tahap desain yang dilakukan untuk merancang konsep dari produk yang akan dikembangkan sesuai dengan hasil dari tahap analisis. Pada tahap ini dilakukan perancangan storyboard dan flowchart yang akan digunakan sebagai pedoman dalam mengembangkan video animasi. Selain itu pada tahap ini juga dilakukan pemilihan dan penentuan aplikasi dan perangkat yang digunakan dalam proses mengembangkan video animasi. Pembuatan flowchart dan storyboard diakukan dengan tujuan untuk mempermudah memahami alur kerja dan prosedur pembuatan dari media pembelajaran video animasi yang akan dikembangkan. Kemudian isi dari media pembelajaran video animasi ini tentunya juga memiliki rancangan yang perlu dipersiapkan. Pada bagian isi dirancang skenario cerita yang akan menadi bahan utama dari cerita video animasi ini. Pada tahap ini juga dilakukan penyusunan perangkat pembelajaran berupa rencana pelaksanaan pembelajaran harian (RPPH) yang akan digunakan sebagai pedoman untuk melaksanakan proses pembelajaran. Selain itu dilakukan juga penyusunan kuesioner yang akan digunakan untuk mengetahui validitas produk yang dikembangkan. Kuesioner nantinya akan dibagikan kepada ahli isi pembelajaran, ahli desain pembelajaran, ahli media pembelajaran dan subjek uji coba produk yaitu uji coba perorangan.

Tahap ketiga yakni tahap pengembangan media. Langkah dari pengembangan ini meliputi beberapa kegiatan membuat, dan memodifikasi bahan ajar. Pada tahap ini dilakukan pemilihan bahan dan unsur dalam video animasi. Bahan dan unsur yang dimaksud seperti pemilihan gambar, warna, suara, dan teks yang digunakan pada video animasi. Selain itu pada tahap ini juga dilakukan seleksi secara mendalam pada unsur serta materi yang akan digunakan pada video. Tampilan video animasi dibuat memuat teks, gambar dan background. Gambar-gambar yang digunakan pada video animasi adalah gambar karakter yang menarik dan berhubungan dengan materi. Pada video animasi juga terdapat suara, suara yang digunakan yaitu suara manusia, musik pengiring dan sound effect. Tidak hanya itu pada media pembelajaran video animasi juga berisikan soal-soal yang nantinya akan diberikan kepada anak untuk menjadi evaluasi media tersebut. Soal-soal evaluasi dibuat dan dikembangkan sekreatif mungkin untuk bisa menarik minat dan motivasi anak untuk menjawab soal.

Tahap pengembangan keempat yakni tahap implementasi. Tahp implementasi dilakukan dengan menguji validitas media oleh ahli dan diuji cobakan pada subjek untuk mengetahui respon dari pengguna media tersebut. Akibat dari pandemi maka pada tahap implementasi hanya bisa dilaksanakan pada uji coba perorangan. Setelah tahap implementasi selesai dilakukan pengembangan dilanjutkan pada tahap evaluasi. Tahap ini dilakukan untuk mengumpulkan data-data dalam setiap tahap yang telah dilakukan dan melihat apakah produk yang dikembangkan telah sesuai dengan apa yang diharapkan. Pada tahap ini juga akan dilakukan proses membandingkan hasil dari uji coba produk yang dilakukan oleh para ahli. Tahap evaluasi dilakukan secara formatif, kegiatan evaluasi dilakukan selama proses pengembangan produk media pembelajaran tujuannya yaitu untuk menghindari terjadinya kesalahan pada hasil akhir produk. Hasil uji validitas pengembangan media video animasi menurut uji ahli ahli isi pembelajaran, ahli desain pembelajaran, ahli media pembelajaran dan hasil uji coba produk pada anak, secara ringkas disajikan pada tabel 5 .

Tabel 5. Persentase Hasil Validitas Media Video animasi

\begin{tabular}{cccc}
\hline No & \multicolumn{1}{c}{ Subjek Uji Coba } & Hasil Validitas (\%) & Kualifikasi Persentase \\
\hline 1. & Uji Ahli Isi Pembelajaran & 100 & Sangat Baik \\
2. & Uji Ahli Desain Pembelajaran & 85 & Baik \\
3. & Uji Ahli Media Pembelajaran & 83 & Baik \\
4. & Uji Coba Perorangan & 93 & Sangat Baik \\
\hline
\end{tabular}

Berdasarkan hasil uji coba produk yang telah dilakukan oleh ahli isi pembelajaran memperoleh hasil persentase skor $100 \%$ dengan kualifikasi sangat baik. Ahli desain pembelajaran memperoleh hasil persentase skor 85\% dengan kualifikasi baik. Ahli media pembelajaran memperoleh hasil persentase skor 83\% dengan kualifikasi baik. Hasil uji coba perorangan memperoleh hasil persentase skor 93\% dengan kualifikasi sangat baik. Dari hasil uji coba dapat disimpulkan bahwa produk video pembelajaran yang dikembangkan sangat layak digunakan dalam proses pembelajaran.

\section{Pembahasan}

Berdasarkan analisis hasil penelitian didapatkan hasil bahwa pengembangan video animasi memperoleh hasil sangat baik. Hal ini dapat dilihat berdasarkan hasil uji validitas dan hasil uji perorangan. Adapun pembahasan mengenai hasil uji validitas dan hasil uji perorangan adalah sebagai 
berikut. Hasil uji validitas yang dilakukan oleh ahli isi pembelajaran memperoleh skor 100\% dengan kualifikasi sangat baik. Hal ini dikarenakan aspek kurikulum, aspek isi/materi dan aspek Kebahasaan yang disajikan pada media telah sesuai dengan karakteristik serta kebutuhan anak usia dini. Dimana pada hakikatnya anak usia dini memiliki karakteristik kognitif yang cenderung belajar dari hal-hal yang bersifat konkret dengan menggunakan bahasa yang sederhana. Materi pembelajaran yang disajikan dalam bentuk digital berupa vidio animasi merupakan suatu hal yang menarik bagi siswa, karena melalui vidio serta gambar-gambar yang menarik tersebut anak dapat menemukan hal-hal baru. Guru sebagai pengajar, pendidik, dan pemimpin memiliki peran dan tanggung jawab terhadap pencapaian peserta didik dalam proses pembelajaran (Fazriah et al., 2021). Baik atau buruknya hasil dari proses pembelajaran menjadi tanggung jawab guru sebagai pendidik. Maka dari itu guru sebagai tenaga pendidik profesional perlu merancang dan mempersiapkan pembelajaran dengan sebaik mungkin.

Selanjutnya pada hasil uji validitas yang dilakukan oleh ahli desain pembelajaran diperoleh skor 85\% dengan kualifikasi baik. Pencapaian hasil tersebut dipengaruhi oleh beberapa hal yaitu materi yang disampaikan sudah sesuai dengan kompetensi dasar, indikator dan tujuan pembelajaran, materi yang disampaikan pendidik mudah dipahami, penggunaan gambar, simbol, warna dan bahasa yang digunakan dalam penyampaian materi, metode pembelajaran yang memudahkan anak memahami pelajaran. Pembelajaran pada anak usia dini perlu disesuaikan dengan karakteristik anak. Penggunaan warna, simbol, serta gambar yang menarik akan dapat meningkatkan ketertarikan serta motivasi siswa untuk beajar dan memperhatikan vidio dengan seksma. Pembelajaran pada anak usia dini dirancang dengan metode bermain sambil belajar, karena permainan merupakan salah satu cara yang menyenangkan dan dapat diterapkan dalam pembelajaran anak usia dini untuk menigkatkan motivasi atau antusias anak dalam belajar (Aprinawati, 2017; Zaini \& Dewi, 2017). Dengan menggunakan metode bermain sambil belajar, anak memiliki motivasi tersendiri untuk belajar dan guru terbantu untuk membuat proses pembelajaran yang kreatif.

Hasil uji validitas yang dilakukan oleh ahli media pembelajaran memperoleh skor 83\% dengan kualifikasi baik. Aspek penilaian media pembelajaran video animasi dinilai dari aspek kelayakan, ketepatan dan tampilan. Dari komentar ahli media pembelajaran secara keseluruhan media sudah bagus terutama dari segi tampilan dan suara narator memiliki suara yang ekspresif dan terdengar dengan jelas sehingga dapat memotivasi anak dalam pembelajaran. Hasil penilaian dari ahli media pembelajaran dapat dikatakan bahwa media pembelajaran video animasi yang dikembangkan sangat layak, sehingga dapat diterapkan untuk anak dalam kegiatan pembelajaran. Media pembelajaran memegang peranan penting dalam proses pembelajaran yang berfungsi menyampaikan informasi kepada pengguna media (Maslina, 2020; Andriyani et al., 2020). Maka dari itu media pembelajaran dapat dimaksimalkan untuk membantu guru dalam memperjelas hal yang ingin disampaikan dan membuat pembelajaran lebih inovatif.

Pada hasil uji coba perorangan diperoleh skor 93\% dengan kualifikasi sangat baik. Untuk dapat mencapai kualifikasi tersebut ada beberapa hal yang membuat anak tertarik dan antusias untuk belajar, yakni media pembelajaran video animasi ini membuat anak senang dan termotivasi dalam menyimak pembelajaran yang diberikan. Penjelasan materi melaui media pembelajaran video animasi dapat dengan mudah dipahami oleh anak. Media pembelajaran video animasi dilengkapi dengan gambar bergerak, tulisan dan suara yang mempermudah anak untuk belajar dan mengingat materi yang ada di dalam media tersebut. Permainan serta animasi adalah hal yang paling disenangi oleh anak usia dini, karena pada dasarnya anak usia dini memang lebih suka bermain. Anak usia dini cenderung lebih suka bermain dan lebih tertarik dengan dunia fantasinya sendiri (Syarifah, 2020; Jamun \& Momang, 2021). Hal tersebut dapat dimanfaatkan oleh guru untuk menyelipkan kegiatan bermain dalam proses pembelajaran untuk bisa menarik perhatian anak.

Video animasi bertema Tri Hita Karana merupakan media interaktif karena mampu merespon siswa melalui pilihan materi yang dapat dipilih siswa secara mandiri, terdapat games dan terdapat evaluasi yang hasilnya dapat dilihat langsung oleh siswa (Apriliani et al., 2020). Kemudian video yang dikembangakan bertema Tri Hita Karana kearifan lokal Bali yang dapat memberikan manfaat pada ranah afektif anak usia dini. Pengamalan Tri Hita Karana dapat membiasakan siswa untuk selalui menjaga keharmonisan hubungan dengan lingkungan, dengan sesama manusia dan dengan tuhan dengan cara selau berbuat baik menjaga sikap, perkataan dan perbuatan. Hasil penelitian ini sejalan dengan beberapa hasil penelitian sebelumnya yang juga menyatakan bahwa bahwa media video animasi bermuatan Tri Hita Karana memiliki kualifikasi baik, sehingga layak untuk dikembangkan dan dibelajarkan kepada siswa (Mahardika et al., 2019). Penelitian selanjutnya juga menyatakan bahwa video pembelajaran berbasis Tri Hita Karana memiliki kekhasan dengan memvisualisasikan nilai-nilai Tri Hita karana sehingga tertanam nilai-nilai karakter pada siswa, sehingga sangat valid dan layak digunakan pada muatan IPS kelas V SD (Wahyudi et al., 2021). Penelitian lainnya juga mengungkapkan hal serupa mengenai penggunaan media 
video animasi, dimana video animasi layak diterapkan dalam pembelajaran anak usia dini (Dewi et al., 2021).

Berdasarkan pembahasan hasil penelitian yang kemudian didukung oleh hasil penelitian sebelumnya dapat dikatakan bahwa media video animasi sangat layak digunakan dalam proses pembelajaran anak, selain itu penggunaan konsep Tri Hita Karana juga mampu menanamkan nilai-nilai sosial yang positif kepada anak. Implikasi penelitian ini yakni dapat membantu guru dalam proses pembelajaran daring khususnya pada penggunaan media pembelajaran. Video animasi yang dikembangkan ini dapat menjadi media pembelajaran yang memiliki daya tarik tersendiri bagi anak, sehingga dapat meningkatkan antusias anak dalam mengikuti pembelajaran.

\section{SIMPULAN}

Berdasarkan analisis hasil penelitian dan pembahasan dapat ditarik kesimpuan bahwa media video animasi media video animasi bertema Tri Hita Karana sangat valid dan layak untuk dikembangkan karena, mampu meningkatkan kemampuan afektif anak. Hasil ini dapat dilihat berdasarkan pada hasil uji validitas dan uji coba perorangan.

\section{DAFTAR RUJUKAN}

Agung, A. A. G. (2014). Buku Ajar Metodelogi Penelitian Pendidikan. Aditya Media Publishing.

Akbar, N. T. (2016). Pengembangan Multimedia Interaktif Ipa Berorientasi Guided Inquiry Pada Materi Sistem Pernapasan Manusia Kelas V SDN Kebonsari 3 Malang. Jurnal Pendidikan, 1(6), 1120-1126. https://doi.org/10.17977/jp.v1i6.6456.

Andriyani, A., Dewi, H. I., \& Zulfitria, Z. (2020). Penggunaan Multimedia Dan Animasi Interaktif Terhadap Keterampilan Membaca Permulaan Siswa. Instruksional, 172. https://doi.org/10.24853/instruksional.1.2.172-180.

Apriliani, E. I., Purwanti, K. Y., \& Riani, R. W. (2020). Peningkatan Kesantunan Bahasa Anak Usia Dini melalui Media Pembelajaran Interaktif Budaya Jawa. Jurnal Obsesi : Jurnal Pendidikan Anak Usia Dini, 5(1), 150. https://doi.org/10.31004/obsesi.v5i1.319.

Aprinawati, I. (2017). Penggunaan Media Gambar Seri Untuk Meningkatkan Kemampuan Berbicara Anak Usia Dini. Jurnal Obsesi : Jurnal Pendidikan Anak Usia Dini, 1(1), 72. https: //doi.org/10.31004/obsesi.v1i1.33.

Ardithayasa, I. W., \& Yudiana, K. (2020). Model Pembelajaran Group Investigation (GI) Berbasis Tri Hita Karana Terhadap Hasil Belajar IPA. Jurnal Ilmiah Sekolah Dasar, 4(2), 163. https://doi.org/10.23887/jisd.v4i2.25105.

Ariesca, Y., Dewi, N. K., \& Setiawan, H. (2021). Analisis Kesulitan Guru Pada Pembelajaran Berbasis Online Di Sekolah Dasar Negeri Se-Kecamatan Maluk Kabupaten Sumbawa Barat. Progres Pendidikan, 2(1), 20-25. https://doi.org/10.29303/prospek.v2i1.86.

Artana, I. (2016). Tri Hita Karana Meningkatkan Kualitas Modal Manusia Dari Persfektif Kesehatan. PIRAMIDA Jurnal Kependudukan Dan Pengembangan Sumber Daya Manusia, 10(2), 100-105. https://doi.org/https://ojs.unud.ac.id/index.php/piramida/article/download/18699/12187.

Dewi, N. W. U. R., Asril, N. M., \& Wirabrata, D. G. F. (2021). Meningkatkan Kemampuan Berhitung Permulaan pada Anak Usia Dini Melalui Video Animasi. Jurnal Pendidikan Anak Usia Dini Undiksha, 5(1), 99-106. https: //doi.org/10.23887/paud.v9i2.36800.

Dewi, T. A. P., \& Sadjiarto, A. (2021). Pelaksanaan Pembelajaran Daring Pada Masa Pandemi Covid-19. Jurnal Basicedu, 5(4), 1909-1917. https://doi.org/10.31004/basicedu.v5i4.1094.

Fazriah, S. L., Hafshah, T. A., \& Maranatha, J. R. (2021). Penggunaan Media Film Animasi Bisu Untuk Stimulasi Perkembangan Anak Usia Dini TK Kemala Bhayangkari 10 Purwakarta. Jurnal Upiedu, 1(1), 22-27. https://ejournal.upi.edu/index.php/IJOCSEE/article/view/33199.

Fitri, N., \& Idris, M. (2019). Nilai Pendidikan Islam dalam Qur'an Surah Luqman Ayat 1-19: Tinjauan Kognitif, Afektif, dan Psikomotorik. Al-Musannif: Journal of Islamic Education and Teacher Training, 1(1), 32-46. https://doi.org/https://doi.org/10.5281/zenodo.2667704.

Hafizah, S. (2020). PENGGUNAAN Dan Pengembangan Video Dalam Pembelajaran Fisika. Jurnal Pendidikan Fisika, 8(2), 225. https://doi.org/10.24127/jpf.v8i2.2656

Hasanah, A., \& Muryanti, E. (2019). Pengaruh Penggunaan Media Diorama terhadap Perkembangan Kemampuan Motorik Halus Anak Usia Dini. Aulad: Journal on Early Childhood, 2(2), 1-7. https://doi.org/10.31004/aulad.v2i2.29. 
Isbayani, N. S., Sulastri, N. M., \& Tirtayani, L. A. (2015). Penerapan Metode Outbound Untuk Meningkatkan Keterampilan Sosial Emosional Anak. Jurnal Pendidikan Anak Usia Dini Universitas Pendidikan Ganesha, 41(5), 430-443. https://doi.org/10.23887/paud.v3i1.6148.

Jaelani, A., Fauzi, H., Aisah, H., \& Zaqiyah, Q. Y. (2020). Penggunaan Media Online Dalam Proses Kegiatan Belajar Mengajar PAI Dimasa Pandemi Covid-19 (Studi Pustaka dan Observasi Online). Jurnal IKA PGSD (Ikatan Alumni PGSD) UNARS, 8(1), 12. https://doi.org/10.36841/pgsdunars.v8i1.579.

Jamun, Y. M., \& Momang, H. D. (2021). Pengembangan Aplikasi Pembelajaran Kesantunan Berbahasa Anak Usia Dini Berbasis Multimedia. Jurnal Anak Usia Dini Dan Pendidikan Anak Usia Dini, 7(1), 7-20. https://doi.org/10.30651/pedagogi.v7i1.6209.

Luthfiyah, E., \& Rakhmawati, N. I. S. (2018). Pengembangan Permainan Domino Angka terhadap Kemampuan Mengenal Lambang Bilangan 1-10 Anak Usia 4-5 Tahun. PAUD Teratai, 7(2), 1-8. https://jurnalmahasiswa.unesa.ac.id/index.php/paud-teratai/article/view/24150.

Mahardika, G. Y., Sindu, I. G. P., \& Suyasa, P. W. A. (2019). Pengembangan Video Pembelajaran Tri Hita Karana Dan Catur Guru Dalam Mata Pelajaran Agama Hindu Untuk Siswa Kelas V Sekolah Dasar "Studi Kasus SDN 1 Tangguwisia." Kumpulan Artikel Mahasiswa Pendidikan Teknik Informatika (KARMAPATI)

$8(3)$,

500-509. https://ejournal.undiksha.ac.id/index.php/janapati/article/viewFile/9922/6298.

Mandra, I. W., \& Dhammananda, D. (2020). Implementation Of Tri Hita Karana Teaching To Form Students Characters Quality. Jurnal Penjaminan Mutu, 6(1), 60-67. https://doi.org/10.25078/jpm.v6i1.1300.

Maslina, A. S. A. A. (2020). Pengembangan Bahan Ajar Ipa Dengan Media Audio Visual Pada Tema Selamatkan Makhluk Hidup Di Pendidikan Dasar. Jurnal JPSD (Jurnal Pendidikan Sekolah Dasar), 7(1), 70-80. https://doi.org/10.12928/jpsd.v7i1.14467.

Muammar, M., \& Suhartina, S. (2018). Media Pembelajaran Berbasis Teknologi Informasi dalam Meningkatkan Minat Belajar Akidah Akhlak. KURIOSITAS: Media Komunikasi Sosial Dan Keagamaan, 11(2), 176-188. https://doi.org/10.35905/kur.v11i2.728.

Muhson, A. (2010). Pengembangan Media Pembelajaran Berbasis Teknologi Informasi. Jurnal Pendidikan Akuntansi Indonesia, 8(2). https://doi.org/10.21831/jpai.v8i2.949.

Nasution, N., Yaswinda, Y., \& Maulana, I. (2019). Analisis Pembelajaran Berhitung melalui Media Prisma Pintar pada Anak Usia Dini. Jurnal Obsesi: Jurnal Pendidikan Anak Usia Dini, 4(1), 240. https://doi.org/10.31004/obsesi.v4i1.311.

Nofikasari, I., Suryani, F., \& Yuliana, M. E. (2019). Induksi Teknologi Media Pembelajaran Berbasis Multimedia Interaktif Pada Paud Aisiyah Al- Hasanah Sukoharjo. Jurnal Pendidikan Anak Usia Dini Undiksha, 1(1), 3-5. http://ejurnal.unisri.ac.id/index.php/sndms/article/view/3264.

Nuraeni, L., Andrisyah, A., \& Nurunnisa, R. (2019). Efektivitas Program Sekolah Ramah Anak dalam Meningkatkan Karakter Anak Usia Dini. Jurnal Obsesi : Jurnal Pendidikan Anak Usia Dini, 4(1), 20. https://doi.org/10.31004/obsesi.v4i1.204.

Nurjanah, E. (2017). Teknik dan Instrumen Asesmen PAUD Ranah Afektif: Teknik Non Tes. At-Ta'lim: Jurnal Pendidikan, 3(1), 25-38. https://ejournal.inzah.ac.id/index.php/attalim/article/view/291.

Pradilasari, L., Gani, A., \& Khaldun, I. (2019). Pengembangan Media Pembelajaran Berbasis Audio Visual pada Materi Koloid Untuk Meningkatkan Motivasi dan Hasil Belajar Siswa SMA. 07(01), 9-15. https://doi.org/10.24815/jpsi.v7i1.13293.

Priyanto, A. (2014). Pengembangan Kreativitas Pada Anak Usia Dini Melalui Aktivitas Bermain. Jurnal Ilmiah Guru Caraka Olah Pikir Edukatif, https://journal.uny.ac.id/index.php/cope/article/view/2913/2434 (diakses.

Rahmayani, A., Siswanto, J., \& Budiman, M. A. (2019). Pengaruh Model Pembelajaran Discovery Learning Terhadap Hasil Belajar Siswa. Jurnal Pendidikan Dan Kewirausahaan, 7(1), 93-108. https://doi.org/10.47668/pkwu.v7i1.20.

Rosalina, C. D., \& Nugrahani, R. (2019). Pengembangan Media Buku Pop-up Untuk Pembelajaran Mengenal Huruf Alphabet Anak Usia Dini. Seling:Jurnal Program Studi PGRA, 5(1), 54-63. https://doi.org/https://doi.org/10.29062/seling.v5i1.362.

Suandi, A., \& Pamungkas, P. D. A. (2019). Multimedia Interaktif Pembelajaran Ips Kelas 7 Berbasis Android Pada Mts Al-Wasliyah Jakarta Timur. JIPI (Jurnal Ilmiah Penelitian Dan Pembelajaran Informatika), 4(2), 66. https://doi.org/10.29100/jipi.v4i2.1087.

Suartama, I. K. (2016). Evaluasi dan Kriteria Kualitas Multimedia Pembelajaran. Universitas Pendidikan Ganesha.

Sudaryono, Desrianti, D. I., \& Maulida, S. N. (2018). Media Animasi Interaktif Untuk Anak Usia Dini Pada Ra Yasir Tangerang. ICIT Journal, 4(2), 168-179. https://doi.org/10.33050/icit.v4i2.91.

Tegeh, I. M. (2014). Model Penelitian Pengembangan. Graha Ilmu. 
Wahyudi, I. M. D., Agung, A. A. G., \& Sujana, W. (2021). Pengembangan Video Pembelajaran Berbasis Tri Hita Karana Pada Muatan Pelajaran IPS Kelas V SD. Jurnal Pedaagogi Dan Pembelajaran, 4(1), 4958. https://ejournal.undiksha.ac.id/index.php/JP2/article/view/32105/18009.

Wirman, A., Yulsyofriend, Y., Yaswinda, Y., \& Tanjung, A. (2018). Pengunaan Media Moving Flahscard Untuk Stimulasi Kemampuan Literasi Anak Usia Dini. Early Childhood: Jurnal Pendidikan, 2(2b), 54-62. https://doi.org/10.35568/earlychildhood.v2i2b.290.

Wulandari, I. A. G., \& Suyanta, I. W. (2019). Guru Kreatif Anak Usia Dini Melalui Pendekatan Taksonomi Bloom. Pratama Widya: Jurnal Pendidikan Anak Usia Dini, 3(2), 37-40. https://doi.org/10.25078/pw.v3i2.736.

Zaini, H., \& Dewi, K. (2017). Pentingnya Media Pembelajaran Untuk Anak Usia Dini. Raudhatul Athfal: Jurnal Pendidikan Islam Anak Usia Dini, 1(1), 81-96. https://doi.org/10.19109/ra.v1i1.1489. 